\title{
Risk factors and the absence of coronary "heart disease in aborigines in West Malaysia
}

\author{
C. J. Burns-Cox, ${ }^{1}$ Y. H. Chong, and R. Gillman \\ From the Department of Medicine, University of Malaya, and the Division of Nutrition \\ - and Division of Rural Health Research (Hooper Foundation), \\ Institute of Medical Research, Kuala Lumpur, Malaysia
}

* Coronary heart disease has never been found in Malaysian aborigines. We report the position regarding some of the risk factors usually associated with coronary heart disease in 73 adult aborigine men.

They lived a physically active life on a diet largely of unrefined carbohydrate in the jungles of central West Malaysia. None was obese and blood pressures remained low at all ages. While the mean serum cholesterols were low, varying between 141 and $156 \mathrm{mg} / 100 \mathrm{ml}$ at different ages, the mean fasting serum triglyceride levels of 135 to $164 \mathrm{mg} / \mathrm{I} 00 \mathrm{ml}$ were comparable with those found in the West. This may have been due to their high carbohydrate intake.

The mean packed cell volume, serum albumin, and erythrocyte transketolase activity were normal, indicating that they were likely to have been adequately nourished.

- Isolated aborigines living deep in the jungle had significantly lower serum lipids and higher gamma-globulin levels than those living at the fringe in contact with the rest of Malaysian society.

$\rightarrow$

Some communities in the world have a very low incidence of coronary heart disease.

As people from such communities change their way of life and adopt Western habits coronary heart disease may appear, though it it not known why. A good example of this is that of the African negroes who suffer very

* little from coronary heart disease in their homeland but have acquired in the U.S.A. a frequency similar to that of the white American. This may be related to such risk factors

- as hypertension, diabetes mellitus, and raised serum cholesterol, all of which have been reported to increase in populations moving from - a rural to an urban society such as the Easter Islanders moving to South America (CruzCoke, Etcheverry, and Nagel, 1964), Yemenite Jews moving to Israel (Cohen, Bavly, and

- Poznanski, 196I), and Japanese moving to Hawaii and the U.S.A. (Keys et al., 1958).

From previous reports (Polunin, 1953; J. M. Bolton, 197I, personal communication) and our own experience we believed that coronary heart disease did not occur in West Malaysian aborigines but knew it to be comReceived 8 February 1972.

1 Present address: Frenchay Hospital, Bristol. mon in Malays, Chinese, and Indians living in the same country (Khaira, I96I). At necropsies on aborigines, Prathap (I97I, personal communication) has found lipid streaking and uncomplicated fibrous plaques but no complicated atheroma in the aorta or coronary arteries.

The aborigines are thin, extremely fit physically, and for many centuries have lived in the dense hilly jungles of central West Malaysia. They have a high rate of infestation with intestinal worms and malaria but appear well nourished. Their diet consists chiefly of hand-milled rice as a staple, supplemented with cassava, millet, maize, fish, and fruit, nearly all of which they grow or gather themselves. Dairy produce is taken only in very small quantities in the form of reconstituted powdered milk and it is the large volume of starchy foods which accounts for their bulky diet. No satisfactory study of the exact calorie, carbohydrate, fat, or protein intake has been carried out. Their traditional ways are slowly changing with the introduction of cash crops, transport, schools, medical services, and new Government-built settlements near towns. 


\section{Subjects and methods}

Seventy-three aborigine men over the age of 24 were studied in the Aborigine Hospital, Gombak, Kuala Lumpur. This hospital is the centre of the Aborigine Medical Service and at the same time provides a meeting place for those on a visit to the town from the jungle. Any male visitor over 24 who appeared healthy was invited to help in the study but was subsequently rejected if a medical history, examination, or chest $x$-ray revealed any serious disease such as rheumatic heart disease or tuberculosis. None had clinical coronary heart disease or glycosuria, and splenomegaly was not considered a ground for exclusion.

The men were divided into three age groups, $25-34,35-44$, and 45 years and over. They were also divided into two groups on the basis of the whereabouts of their homes; those living on the fringe of the jungle sometimes earning money and in frequent contact with outside society, shops, and medical service, and those living very much more isolated lives in deep jungle.

Height $(\mathrm{cm})$ and weight $(\mathrm{kg})$ in underclothes were recorded and from them an obesity index (weight/height ${ }^{2}$ ) was calculated. After five minutes rest supine, the blood pressure was recorded with a mercury sphygmomanometer. Readings were taken to the nearest $5 \mathrm{mmHg}$ and the diastolic pressure was taken at the point of sudden muffling of sound. A I2-lead standard electrocardiogram was recorded at $25 \mathrm{~mm} / \mathrm{sec}$ and rate, $\mathrm{QRS}$ axis, $\mathrm{PR}$, and $\mathrm{QT} \mathrm{T}_{\mathrm{c}}$ intervals measured. Each tracing was analysed for items in the Minnesota code (Blackburn et al., 1960) believed especially relevant to coronary heart disease as follows. Abnormal $Q$ waves and left axis deviation, ST and $T$ depression and inversion, complete heart block, and complete bundle-branch block (codes I.I-4, 2.I, 4.I-3, 5.I-3, 6.I, and 6.3). The $R$ waves in $V_{5}$ and V6 were measured and added to the $S$ wave in VI.

Venous blood taken after an overnight fast was examined for packed cell volume, erythrocyte transketolase activity, thiamine pyrophosphate stimulating effect (\%TPP effect), serum cholesterol, triglycerides, beta-lipoproteins, and total lipids by methods previously described (Chong and Ho, 1970; Chong et al., 1971). Total serum proteins were estimated by the micro-Kjeldahl procedure (Wootton, 1964) and paper electrophoresis of serum proteins was carried out in the Beckman Model R paper electrophoresis system. Tests were carried out within 3 days on sera stored at $4^{\circ} \mathrm{C}$ except for packed cell volume, erythrocyte transketolase activity, and serum lipoproteins which were carried out within 6 hours of collection.

A 6-foot posteroanterior chest $x$-ray was taken and the cardiothoracic ratio calculated.

\section{Results}

Those under 35 were only slightly heavier and more obese than their elders and the differences are not significant.
TABLE I Mean height, weight, obesity index, and age

\begin{tabular}{lllll}
\hline $\begin{array}{l}\text { Age } \\
(y r)\end{array}$ & $\begin{array}{l}\text { Height } \\
(\mathrm{cm})\end{array}$ & $\begin{array}{l}\text { Weight } \\
(\mathrm{kg})\end{array}$ & $\begin{array}{l}\text { Obesity } \\
\text { index }\end{array}$ & $\begin{array}{l}\text { No. of } \\
\text { subjects }\end{array}$ \\
\hline $25-34$ & $155 \cdot 8 \pm 5 \cdot 3$ & $49 \cdot 8 \pm 4 \cdot 3$ & $205 \pm 16$ & 31 \\
$35-44$ & $155 \cdot 0 \pm 5 \cdot 3$ & $48 \cdot 1 \pm 5 \cdot 1$ & $200 \pm 19$ & 25 \\
$45+$ & $154 \cdot 6 \pm 5 \cdot 8$ & $48 \cdot 0 \pm 6 \cdot 0$ & $200 \pm 20$ & 17 \\
\hline
\end{tabular}

Mean systolic and diastolic pressures were not significantly different in the three groups, being $125 / 79 \mathrm{mmHg}$ aged 25 to $34,117 / 75$ mmHg aged 35 to 44 , and $131 / 79 \mathrm{mmHg}$ aged over 44 .

The mean cardiothoracic ratios in these groups were $47 \cdot 5,46 \cdot 4$, and $47 \cdot 6$. Eight men had ratios greater than 50 , the highest being 56. Their ages, habitats, blood pressures, and electrocardiograms were not different from those of the others.

All lipid measurements showed an increase from the first to the second age groups and all but the cholesterol fell from the second to the third. No change was significant. The mean serum cholesterol of those with a packed cell volume less than 45 was significantly less than that of those with a packed cell volume of 45 or more $(P<0.01)$.

Albumin levels and $A / G$ ratio fell with increasing age. The packed cell volume was found to be higher in the heavier and more obese men $(P<0.05)$, as was the serum albu$\min (P<0.05)$. The $A / G$ ratio was higher in those with a packed cell volume of 45 or more than in those with a packed cell volume less than $45(\mathrm{P}<0.001)$.

Table 4 shows that men from fringe jungle had higher mean serum lipids, albumin, and A/G ratios than those from deep jungle but lower gamma-globulins.

The proportions of those living in deep and fringe jungle were the same in each age group and there was no difference in mean height, weight, obesity index, or cardiothoracic ratio between the two groups. The mean systolic

TABLE 2 Serum lipids and age

\begin{tabular}{|c|c|c|c|c|c|}
\hline Age (yr) & $\begin{array}{l}\text { Cholesterol } \\
(\mathrm{mg} / 100 \mathrm{ml})\end{array}$ & $\begin{array}{l}\text { Triglycerides } \\
(\mathrm{mg} / \mathrm{I} 00 \mathrm{ml})\end{array}$ & $\begin{array}{l}\text { Beta-lipo- } \\
\text { proteins } \\
(\mathrm{mg} / \mathrm{loO} \mathrm{ml})\end{array}$ & $\begin{array}{l}\text { Total lipids } \\
(\mathrm{mg} / \mathrm{IOO} \mathrm{ml})\end{array}$ & $\begin{array}{l}\text { No. } \\
\text { studied }\end{array}$ \\
\hline $\begin{array}{l}25-34 \\
35-44 \\
45+\end{array}$ & $\begin{array}{l}141 \pm 31 \\
156 \pm 34 \\
156 \pm 49 \\
\end{array}$ & $\begin{array}{l}136 \pm 47 \\
165 \pm 74 \\
145 \pm 93\end{array}$ & $\begin{array}{l}263 \pm 95 \\
302 \pm 128 \\
272 \pm 86\end{array}$ & $\begin{array}{l}622 \pm 173 \\
723 \pm 238 \\
655 \pm 169\end{array}$ & $\begin{array}{l}31 \\
25 \\
17\end{array}$ \\
\hline
\end{tabular}


TABLE 3 Serum proteins, erythrocyte transketolase activity as \% TPP effect, packed cell volume, and age

\begin{tabular}{|c|c|c|c|c|c|c|c|}
\hline Age $(y r)$ & $\begin{array}{l}\text { Albumin } \\
(\mathrm{g} / \mathrm{roO} \mathrm{ml})\end{array}$ & $\begin{array}{l}\text { Gamma } \\
\text { globulin } \\
(\mathrm{g} / \mathrm{I} 00 \mathrm{ml})\end{array}$ & $\begin{array}{l}\text { Total protein } \\
(\mathrm{g} / \mathrm{I} 00 \mathrm{ml})\end{array}$ & $A / G$ ratio & $\begin{array}{l}\text { Erythrocyte } \\
\text { transketolase } \\
\text { activity } \\
(\% T P P \text { effect })\end{array}$ & $\begin{array}{l}\text { Packed cell } \\
\text { volume }\end{array}$ & $\begin{array}{l}\text { No. } \\
\text { studied }\end{array}$ \\
\hline $\begin{array}{l}25-34 \\
35-44 \\
45+\end{array}$ & $\begin{array}{l}4 \cdot 30^{\star} \pm 0.49 \\
4.03^{\star} \pm 0.42 \\
4.01 \pm 0.70\end{array}$ & $\begin{array}{l}I \cdot 97 \pm 0.4 I \\
I \cdot 82 \pm 0.55 \\
2 \cdot I 2 \pm 0.83\end{array}$ & $\begin{array}{l}7 \cdot 5 \pm 0.6 \\
7 \cdot 3 \pm 0.5 \\
7 \cdot 5 \pm 0.7\end{array}$ & $\begin{array}{l}I \cdot 4 \pm 0.3 \\
I \cdot 3 \pm 0.3 \\
I \cdot 2 \pm 0.4\end{array}$ & $\begin{array}{l}17 \cdot 6 \pm 7 \cdot 6 \\
I 9 \cdot I \pm I I \cdot I \\
2 I \cdot 6 \pm I I \cdot 7\end{array}$ & $\begin{array}{l}45 \pm 3 \cdot 4 \\
44 \pm 3 \cdot 8 \\
43 \pm 5 \cdot 4\end{array}$ & $\begin{array}{l}31 \\
25 \\
17\end{array}$ \\
\hline
\end{tabular}

$\star=\mathrm{P}<0.05$.

and diastolic pressures of the groups were I $12 / 78 \mathrm{mmHg}$ for those from fringe jungle and I $14 / 72 \mathrm{mmHg}$ for those from deep jungle. - The difference was not significant $(\mathbf{P}>0.3)$.

A record of abdominal examination was available for 58 men. Seven of 14 men ( $50 \%)$ from deep jungle and 13 out of $44 \mathrm{men}(30 \%)$ from fringe jungle had palpably enlarged spleens. This difference may be associated with the higher levels of gamma-globulins in men who lived in deep jungle.

Analysis of electrocardiograms showed no difference between age groups or between deep and fringe jungle dwellers. The only - items in the Minnesota codes listed above were inverted $T$ waves (codes 5.2 in one and 5.3 in one). The inverted $T$ waves were both in lead V2 and both men were under 35. Two

- men had complete right bundle-branch block. In only two men was the R in $V_{5}-6$ added to the $S$ in VI greater than $35 \mathrm{~mm}$ and both men - were under 35 years old. None of the socalled 'Juvenile patterns' described by Grusin (I954) was seen.

Incidental findings Several men had chronic productive coughs and one had mild

- elephantiasis of one leg.

\section{Discussion}

- Numerous factors such as age, sex, obesity, and smoking affect the risks of developing coronary heart disease, but in practice the two most important risk factors are raised serum lipids and raised systemic blood pressure.

Serum cholesterol levels vary widely from one community to another. Most workers, for example Kannel et al. (196I) and Morris et al. (1966), have found the level to be a useful predictor of coronary heart disease. Middleaged men in England (Howell, 1970) have been found to have mean serum cholesterol levels around $250 \mathrm{mg} / 100 \mathrm{ml}$, and such populations show a rise from the age of 20 to 50 followed by a plateau and then a fall. Kalahari bushmen (Tobias, 1966) and other groups have mean levels around $130 \mathrm{mg} / \mathrm{I} 00$ $\mathrm{ml}$ and show no rise with age. Chinese, Indian, and Malay men in Malaysia have mean serum cholesterol levels around $190 \mathrm{mg} / 100 \mathrm{ml}$ (Chong et al., 1971). The mean serum cholesterol of our aborigines was found to be 143 $\mathrm{mg} / 100 \mathrm{ml}$ and though there was some rise with age until 45 , the level was not found to be related to weight, unlike findings in Caucasians in Chicago (Stamler et al., 196I). The serum cholesterol level was higher in those with a high packed cell volume than in others. The association was not due to posture as all patients had been supine for some time when blood was taken. A similar association using haemoglobin levels rather than packed cell volume has been reported for South Pacific Islanders, Pakistanis, Glaswegians, and Welshmen (Elwood et al., 1970), but the mechanism is not known.

TABLE 4 Nutritional biochemistry and habitat

\begin{tabular}{|c|c|c|c|c|c|c|c|c|c|c|c|}
\hline Habitat & $\begin{array}{l}\text { Cholesterol } \\
(\mathrm{mg} / \mathrm{IOO} \\
\mathrm{ml})\end{array}$ & $\begin{array}{l}\text { Triglycer- } \\
\text { ide }(\mathrm{mgl} \\
\text { roo } \mathrm{ml})\end{array}$ & $\begin{array}{l}\text { Beta-lipo- } \\
\text { protein } \\
(\mathrm{mg} / \mathrm{l} 00 \mathrm{ml})\end{array}$ & $\begin{array}{l}\text { Total lipid } \\
(m g / I 00 \\
m l)\end{array}$ & $\begin{array}{l}\text { Albumin } \\
(\mathrm{g} / \mathrm{I} 00 \mathrm{ml})\end{array}$ & $\begin{array}{l}\text { Gamma- } \\
\text { globulin } \\
(\mathrm{g} / \mathrm{roO} \mathrm{ml})\end{array}$ & $\begin{array}{l}\text { Total } \\
\text { protein } \\
(\mathrm{g} / \mathrm{IOO} \mathrm{ml})\end{array}$ & A/G ratio & $\begin{array}{l}\% T P P \\
\text { effect }\end{array}$ & $\begin{array}{l}\text { Packed } \\
\text { cell } \\
\text { volume }\end{array}$ & $\begin{array}{l}\text { No. } \\
\text { studied }\end{array}$ \\
\hline $\begin{array}{l}\text { Fringe } \\
\text { jungle } \\
\text { Deep }\end{array}$ & $158 \pm 36 \neq$ & $148 \pm 74$ & $304 \pm$ rost & $695 \pm 195^{\star}$ & $4.20 \pm 0.45$ & $1.83 \pm 0.56^{\star}$ & $7 \cdot 4 \pm 0.6$ & $1 \cdot 4 \pm 0.3^{\star}$ & $19.0 \pm 10.9$ & $45 \pm 4$ & 51 \\
\hline jungle & $130 \pm 33 \ddagger$ & $142 \pm 57$ & $230 \pm 92 \dagger$ & $588 \pm 171^{\star}$ & $4.00 \pm 0.68$ & $2.22 \pm 0.52^{\star}$ & $7.5 \pm 0.7$ & $1 \cdot 2 \pm 0 \cdot 3^{\star}$ & $18 \cdot 2 \pm 8 \cdot 7$ & $44 \pm 4$ & 22 \\
\hline
\end{tabular}


Albrink, Meigs, and Man (196I) believed the fasting serum triglyceride level to be a better predictor of coronary heart disease than the serum cholesterol level. They found a rise with age in people without coronary heart disease but no relation to age in those with coronary heart disease. Others have found serum triglycerides to be higher in New Yorkers with coronary heart disease than in those without. Differences in serum triglyceride levels have not been found between Malaysian coronary heart disease patients and healthy Malaysian blood donors (Chong et al., 197I), but it must be pointed out that the aborigines have significantly lower lipid and lipoprotein levels than other Malaysians.

The levels of serum triglycerides in this study were surprisingly high. Other male populations studied previously have had levels of $60-100 \mathrm{mg} / 100 \mathrm{ml}$ until early middle age when those on a Western type diet have shown a steep rise to around $190 \mathrm{mg} / \mathrm{I} 00 \mathrm{ml}$ (Antonis and Bersohn, 1960; Schaefer, 1964), while others like the Bantu, on a high starch diet, and Eskimo, on a high fat diet, kept the same level throughout life (Antonis and Bersohn, 1960; Bang, Dyerberg, and Nielsen, 1971). The aborigines had high levels up to the age of 34 with a statistically insignificant rise in middle age and fall afterwards. For a group without ischaemic heart disease these levels are unusual.

There is an impression from the published reports that a high carbohydrate diet may be responsible for high triglyceride levels in a population. There is no doubt that a drastic increase in the carbohydrate content of a diet induces a rise in serum triglyceride levels especially if the carbohydrate is given as sucrose but most experiments have been short term. Antonis and Bersohn (196I) followed subjects for several months after changing from a high fat/low carbohydrate diet to a high carbohydrate/low fat diet; the triglyceride levels rose at once but fell to baseline levels after 12 weeks in Bantus and nearly as far by 17 weeks in white South Africans. On the basis of present evidence the high triglyceride levels found in the aborigines may be accounted for in part by their high carbohydrate diet but there may have been other factors present.

Blood pressure levels showed no rise with age. While communities in the West do show a rise with age (Hamilton et al., 1954), New Guinea villagers (Maddocks and Vines, 1966) and Malaysian aborigines previously studied (Burns-Cox and Maclean, 1970) had low pressures throughout life. Both these studies suggested that chronic infection may have played a part in this. Malaria is hyperendemic in deep jungle in Western Malaysia and, though suppressive therapy is partially successful, men living there more often had splenomegaly and lower systolic and diastolic pressures than those from fringe jungle.

The obesity index used (weight/height ${ }^{2}$ ) has been reported to be a useful measure of obesity in several populations and Florey (1970) in a review found it to be a better measure of obesity in Caucasian men than several others in use. The youngest group of aborigines had a similar mean obesity index (205) to that of Chinese and Malay medical students (Burns-Cox, Lau, and Toh, I97I). In contrast, the mean of a New Zealand Caucasian male population aged 20-29 was 23I which was higher than that found in Englishmen (Evans et al., 1968). These latter and other studies showed a rise into middle age, unlike the present findings and those in New Guinea villagers (Maddocks, 1964).

Rosenman and others (1966) believed persons with great drive, aggressiveness, ambition, and sense of time urgency had a coronary prone personality type. At present Malaysian aborigines definitely do not fulfil these criteria.

The aborigines we studied lived a very strenuous life, often walking long distances over very hilly country, hunting, and growing food. Those who have walked with them will testify that they must be among the fastest and fittest walkers in the world.

Most aborigines smoke many hours daily from childhood and make their cigarettes from locally grown sun-cured tobacco. A small quantity of this rough tobacco is rolled in a leaf and smoked slowly so that an ounce lasts many days. While chronic lung disease, presumably chronic bronchitis and emphysema, is common, carcinoma of the bronchus is exceedingly rare. It may well be that if coronary heart disease is not common in a population cigarette smoking alone is not important in its genesis.

Diabetes mellitus is extremely rare and found only in aborigines living in the lowlands in contact with shops and the Westernstyle life.

The satisfactory serum albumin levels suggest adequate protein nutrition, despite the presence of infections, and were comparable with values obtained by identical methods in a group of well-fed military personnel and civilians in Malaysia (Interdepartmental Committee on Nutrition and National Defence, 1964). The higher serum albumin levels, A/G ratios, and packed cell volume found in heavier and more obese men probably indi- 
cate the combined effects of differences in nutrition and chronic infection.

A percentage TPP effect greater than 25 has previously been found to indicate thiamine deficiency in Malaysians (Chong and Ho, 1970). Levels for those from deep and fringe jungle were the same and only 18 per cent of men had a per cent TPP effect greater than 25 compared to $21-36$ per cent of other - Malaysians.

The deep jungle dwellers may be regarded as less affected by Western dietary and other habits than those living on the fringe. While the cholesterol, beta-lipoprotein, and total lipid levels were all significantly higher in those living on the fringe, the weight and

* obesity were the same. The lower serum albumin and higher gamma-globulin levels of those living in deep jungle suggest increased rate and severity of infection.

No changes on the electrocardiogram associated with or predictive of coronary heart disease were seen. The high voltage of $R$ in

> V5-6 and S in VI was presumed to be due to youth and not left ventricular hypertrophy. Inverted $\mathrm{T}$ waves in $\mathrm{V} 2$ are normal in young people and the changes in the present study

- were regarded as being explained by age.

Malaysian aborigines have very little if any coronary heart disease and appear to be free of the factors known to put people at risk in Western communities. Those living in fringe jungle have begun to adopt some Western habits and have higher serum lipids than

- those isolated in deep jungle. Dietary factors have not been adequately studied and deserve measurement, together with future changes in the risk factors of coronary heart disease in these aborigines.

We are very grateful to Dr. J. M. Bolton, M.B.E., Officer in Charge, Aborigine Medical Services, for his guidance and help.

\section{References}

Albrink, M. J., Meigs, J. W., and Man, E. B. (I96I). Serum lipids, hypertension and coronary artery disease. American fournal of Medicine, 3I, 4.

- Antonis, A., and Bersohn, I. (1960). Serum-triglyceride levels in South Africans, Europeans and Bantu and in ischaemic heart disease. Lancet, $1,998$.

Antonis, A., and Bersohn, I. (I96I). Influence of diet on serum-triglycerides in South African White and

2. Bantu prisoners. Lancet, $\mathbf{I}, 3$.

Bang, H. O., Dyerberg, J., and Nielsen, A. B. (197I). Plasma lipid and lipoprotein pattern in Greenlandic West-Coast Eskimos. Lancet, I, I 143 .

- Blackburn, H., Keys, A., Simonson, E., Rautaharju, P., and Punsar, S. (I960). The electrocardiogram in population studies. Circulation, 21, 1160.
Burns-Cox, C. J., Lau, L. C., and Toh, B. H. (197I). The electrocardiogram of healthy young Chinese and Malay men. Fournal of Electrocardiology, 4, 21 I.

Burns-Cox, C. J., and Maclean, J. D. (1970). Splenomegaly and blood pressure in aborigines in an Orang Asli community in West Malaysia. American Heart fournal, 80, 718.

Chong, Y. H., and Ho, G. S. (1970). Erythrocyte transketolase activity. American fournal of Clinical Nutrition, 23, 261.

Chong, Y. H., Soh, C. C., Ho, C. S., Rajaratnam, R., and Nonis, P. (I97I). Serum low density lipoproteins, triglycerides and cholesterol levels in Malaysia. Clinica Chimica Acta, 34, 85.

Cohen, A. M., Bavly, S., and Poznanski, R. (I96I). Change of diet of Yemenite Jews in relation to diabetes and ischaemic heart disease. Lancet, 2, I399.

Cruz-Coke, R., Etcheverry, R., and Nagel, R. (1964). The influence of migration on blood-pressure of Easter Islanders. Lancet, I, 697.

Elwood, P. C., Mahler, R., Sweetnam, P., Moore, F., and Welsby, E. (1970). The association between circulating haemoglobin level, serum cholesterol, and blood pressure. Lancet, I, 589 .

Evans, J. G., Prior, I. A. M., Davidson, F., and Morrison, R. B. I. (1968). The Carterton Study: Part 2. Height, weight and skinfold measurements. New Zealand Medical fournal, 68, 318.

Florey, C. Du V. (1970). The use and interpretation of ponderal index and other weight-height ratios in epidemiological studies. Fournal of Chronic Diseases, 23, 93.

Grusin, H. (1954). Peculiarities of the African's electrocardiogram and the changes observed in serial studies. Circulation, 9, 860.

Hamilton, M., Pickering, G. W., Roberts, J. A. F., and Sowry, G. S. C. (1954). The aetiology of essential hypertension. 1 . The arterial pressure in the general population. Clinical Science, 13, II.

Howell, R. W. (1970). Social class and biological tests. Lancet, I, 1343 .

Interdepartmental Committee on Nutrition and National Defence (1964). Nutrition Survey, Federation of Malaya, Report, Washington.

Kannel, W. B., Dawber, T. R., Kagan, A., Revotskie, N., and Stokes, J. (I96I). Factors of risk in the development of coronary heart disease - six year follow-up experience. Annals of Internal Medicine, 55, 33.

Keys, A., Kimura, N., Kusukawa, A., Bronte-Stewart, B., Larsen, N., and Keys, M. H. (1958). Lessons from serum cholesterol studies in Japan, Hawaii and Los Angeles. Annals of Internal Medicine, 48, 83.

Khaira, B. S. (196I). The pattern of heart disease in the adult population of Malaya. Medical fournal of Malaya, 16, 81.

Maddocks, I. (1964). Dietary factors in the genesis of hypertension. In Proceedings of the Sixth International Congress on Nutrition, Edinburgh, 1963, p. 137. Livingstone, Edinburgh.

Maddocks, I., and Vines, A. P. (1966). The influence of chronic infection on blood-pressure of New Guinea males. Lancet, 2, 262.

Morris, J. N., Kagan, A., Pattison, D. C., Gardner, M. J., and Raffle, P. A. B. (1966). The incidence and prediction of ischaemic heart disease in London busmen. Lancet, 2, 553.

Polunin, I. (1953). The medical natural history of Malayan aborigines. Medical fournal of Malaya, 8, 55 . 
Rosenman, R. H., Friedman, M., Straus, R., Wurm, M., Jenkins, C. D., and Messinger, H. B. (1966) Coronary heart disease in the Western Collaborative Group Study. Fournal of the American Medical Association, 195, 86.

Schaefer, L. E. (I964). Serum cholesterol - triglyceride distribution in a 'normal' New York City population. American fournal of Medicine, 36, 262.

Stamler, J., Berkson, D. M., Lindberg, H. A., Miller, W., and Hall, Y. (196I). Racial patterns of coronary heart disease. Geriatrics, 16, 382.
Tobias, P. V. (1966). In The Biology of Human Adaptability, p. 190. Ed. by P. T. Baker and J. S. Weiner. Oxford University Press, London.

Wootton, I. D. P. (1964). Micro-Analysis in Medical Biochemistry, 4th ed. J. and A. Churchill, London.

Requests for reprints to Dr. C. J. Burns-Cox, Department of General Medicine, Frenchay Hospital, Bristol. 